\title{
Review
}

Clinical

nephron

Practice

\section{Cardiac and Renal Fibrosis in Chronic Cardiorenal Syndromes}

\author{
Aneley Hundae ${ }^{a}$ Peter A. McCullough ${ }^{a, b}$ \\ a Baylor University Medical Center, Baylor Heart and Vascular Institute, Baylor Jack and Jane Hamilton Heart and \\ Vascular Hospital, Dallas, Tex., and ${ }^{\text {b}}$ The Heart Hospital, Plano, Tex., USA
}

\begin{abstract}
In recent years, there has been considerable interest in cellular and tissue responses to injury that result in the deposition of extracellular matrix, collagen, elastic fibers, and the histopathological development of fibrosis. In the myocardium, fibrosis results in many recognizable clinical features, including PR interval prolongation, heart block, bundle branch block, left ventricular dyssynergy, anisotropy, atrial fibrillation, ventricular arrhythmias, systolic and diastolic dysfunction, heart failure, and cardiac death. In the kidneys, fibrosis in the glomerulus leads to glomerular sclerosis, and in the inner cortex and medulla, tubulointerstitial fibrosis leads to a reduction in renal filtration function and rapidly progressive chronic kidney disease. There are a great number of potential early mediators of cellular damage in response to events such as ischemia, neurohormonal activation, biomechanical stretch, and abnormal cell signaling. However, many studies suggest that interstitial cells in both organs, including macrophages, T lymphocytes, fibroblasts, and myofibroblasts, have common communication systems that utilize galectin- 3 and transforming growth factor- $\beta$ that result in the upregulation and proliferation of fibroblasts and myofibroblasts, which produce and secrete procollagen I. Procollagen I cross-links in the extracellular space to form mature collagen, which is a fundamental unit of organ fibrosis. Future research will be concentrating on the pathogenic mech-
\end{abstract}

anisms that turn on fibrosis and on therapeutic targets that can either prevent the activation of fibroblasts or limit their repair response to injury.

(c) 2014 S. Karger AG, Base

\section{Introduction}

The term 'cardiorenal syndrome' has been reintroduced into the clinical and research literature with the goal of promoting research and understanding of how the heart and kidneys can both promote and promulgate disease in the reciprocal organ system $[1,2]$. Chronic cardiorenal syndromes occur as type 2 , where chronic heart failure promotes and accelerates chronic kidney disease (CKD) [3]. In a reciprocal fashion, type 4 cardiorenal syndrome, also termed 'CKD cardiomyopathy' is the clinical scenario where CKD promotes myocardial disease with many well-characterized changes in the myocardium resulting in clinical heart failure [4]. This review will focus on the process of tissue fibrosis that occurs in both organs

Targeting Recovery from Acute Kidney Injury: Round Table Conference at the 19th International Conference on Continuous Renal Replacement Therapies (Manchester Grand Hyatt, San Diego, Calif., USA, March 2-3, 2014).

\section{KARGER}

E-Mail karger@karger.com

www.karger.com/nec
C 2014 S. Karger AG, Basel

$1660-2110 / 14 / 1274-0106 \$ 39.50 / 0$
Peter A. McCullough, MD, MPH

Baylor Heart and Vascular Institute

621 North Hall Street, H030

Dallas, TX 75226 (USA)

E-Mail peteramccullough@gmail.com 
Fig. 1. Major systemic and local events that play a mechanistic role in the development of chronic cardiorenal syndromes as expressed by measured biomarkers [adapted from 7]. IL-18 = Interleukin-18; KIM-1 = kidney injury molecule-1; L-FABP = livertype fatty acid binding protein; NGAL = neutrophil gelatinase-associated lipocalin.

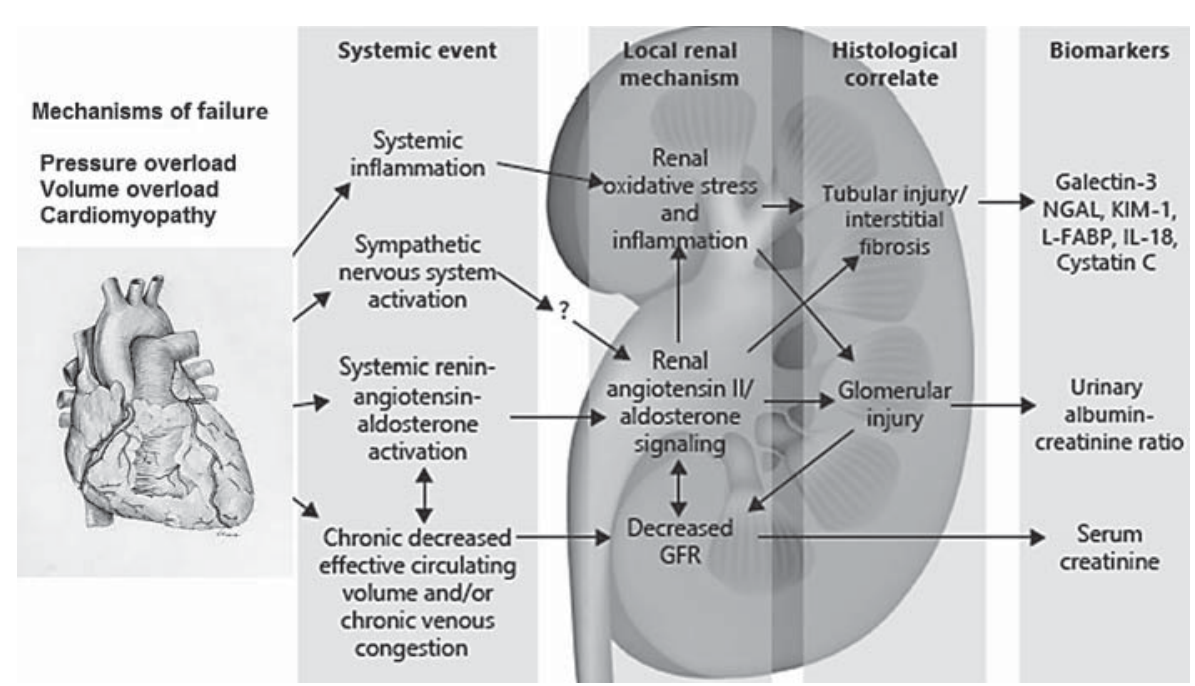

as a result of chronic diseases, including hypertension, diabetes, dysmetabolic syndrome, and obesity [5]. The literature vastly describes many upstream mediators primarily with neurohormones (sympathetic nervous system, renin-angiotensin system, endothelin, and arginine vasopressin) and local cell signaling via immune and satellite cells (interleukins, tumor necrosis factor- $\alpha$, connective tissue growth factor, lysyl oxidase homologue 2, NADPH oxidase, and vascular epithelial growth factor) $[6,7]$. Therefore, with the goal of maintaining focus, we have chosen to concentrate on a common signal influenced by many of these factors, transforming growth factor (TGF)- $\beta$, and discuss its role in both cardiac and renal fibrosis in translation to measurable mediators of chronic cardiorenal syndromes.

\section{Transforming Growth Factor- $\beta$}

In response to tissue injury, the activation of fibroblasts and myofibroblasts is a normal process that enables wound retraction and scar formation in the skin and soft tissues. Normal wound healing relies on the appropriate levels of cytokines and growth factors to ensure that cellular responses are mediated in a coordinated and controlled fashion. Among the many growth factors studied in the context of wound healing, TGF- $\beta$ is thought to have the broadest spectrum of effects and has been of considerable interest in many applications of chronic diseases [8]. The TGF- $\beta$ superfamily consists of a family of $>30$ cytokines that signal via a pair of transmembrane serine-threonine kinase receptors known as type I and II receptors. These receptors, in turn, affect Smad transcription factors to mediate downstream signaling events (fig. 1-7). Although TGF- $\beta$ isoforms signal through the same family of cell surface receptors, they result in different cellular responses in effector cells, including macrophages and fibroblasts. TGF- $\beta$-mediated responses include cell cycle regulation, cell proliferation and differentiation, extracellular matrix (ECM) production, and immune modulation. In the heart, TGF- $\beta$ plays numerous roles, including induction of epithelial-tomesenchymal transition in endocardial cells, which is necessary for normal embryological development. In the heart and kidneys, as well as other organs, TGF- $\beta$ also has several roles in normal tissue homeostasis, regulating diverse functions, such as cellular differentiation, apoptosis, cell-cycle arrest, ECM production, and cellular migration.

\section{Biomechanical Stretch, Ischemia, and Infarction in the Myocardium}

Uniquely, the heart has the greatest constant motion of all internal organs and, thus, the myocardium both generates and responds to biomechanical stretch. Wall tension is determined by the radius of the chamber, its internal pressure, and the thickness of the wall. Cardiac ischemia results in transient increases in left ventricular wall tension. In the setting of myocardial infarction, there is a marked increase in wall tension not only of the infarct-related segment of the myocardium but also in the uninvolved or reference segments, which respond with 


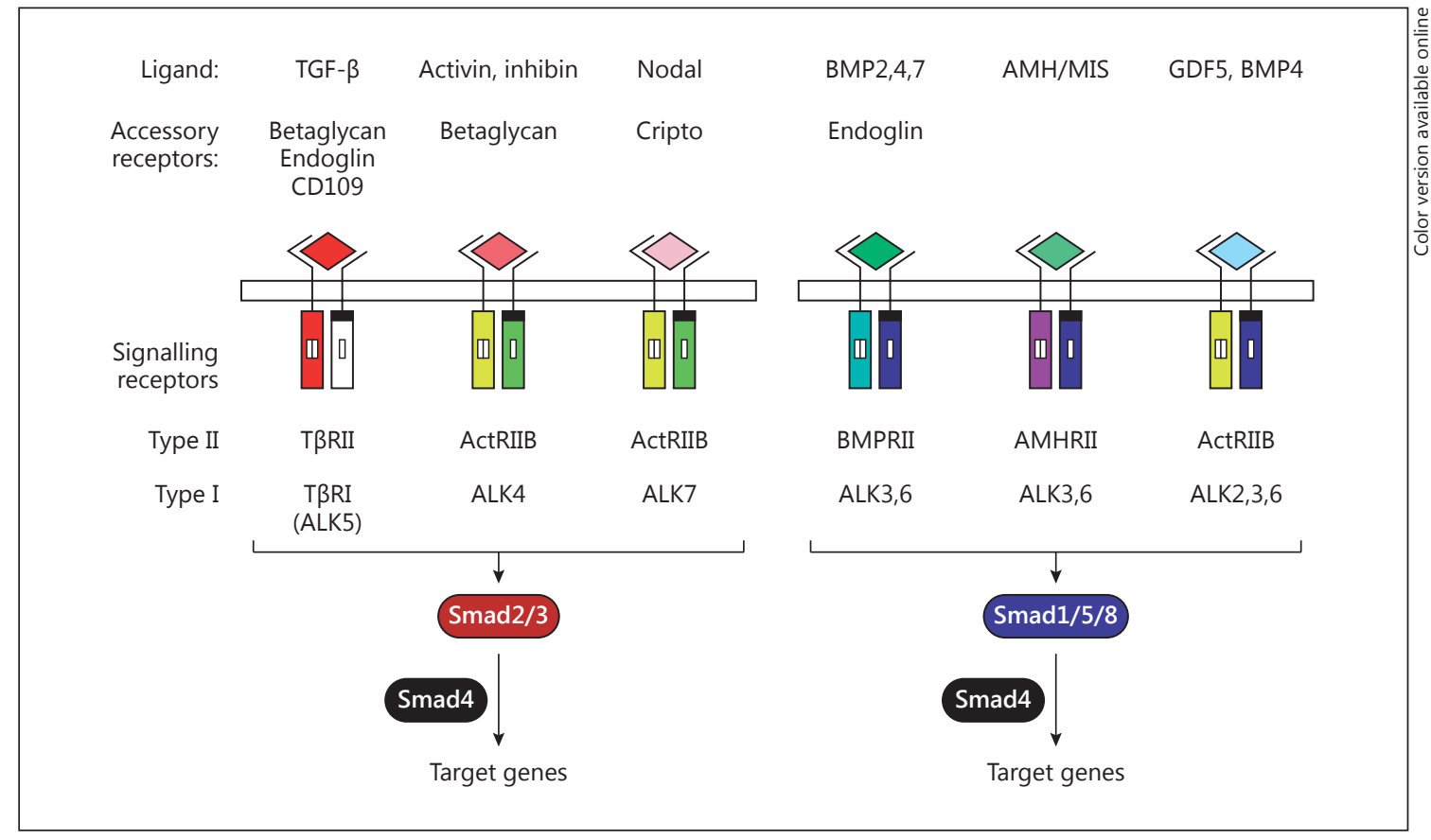

Fig. 2. TGF- $\beta$ family of ligands and receptors that mediate cellular changes associated with fibrosis [adapted from 8].

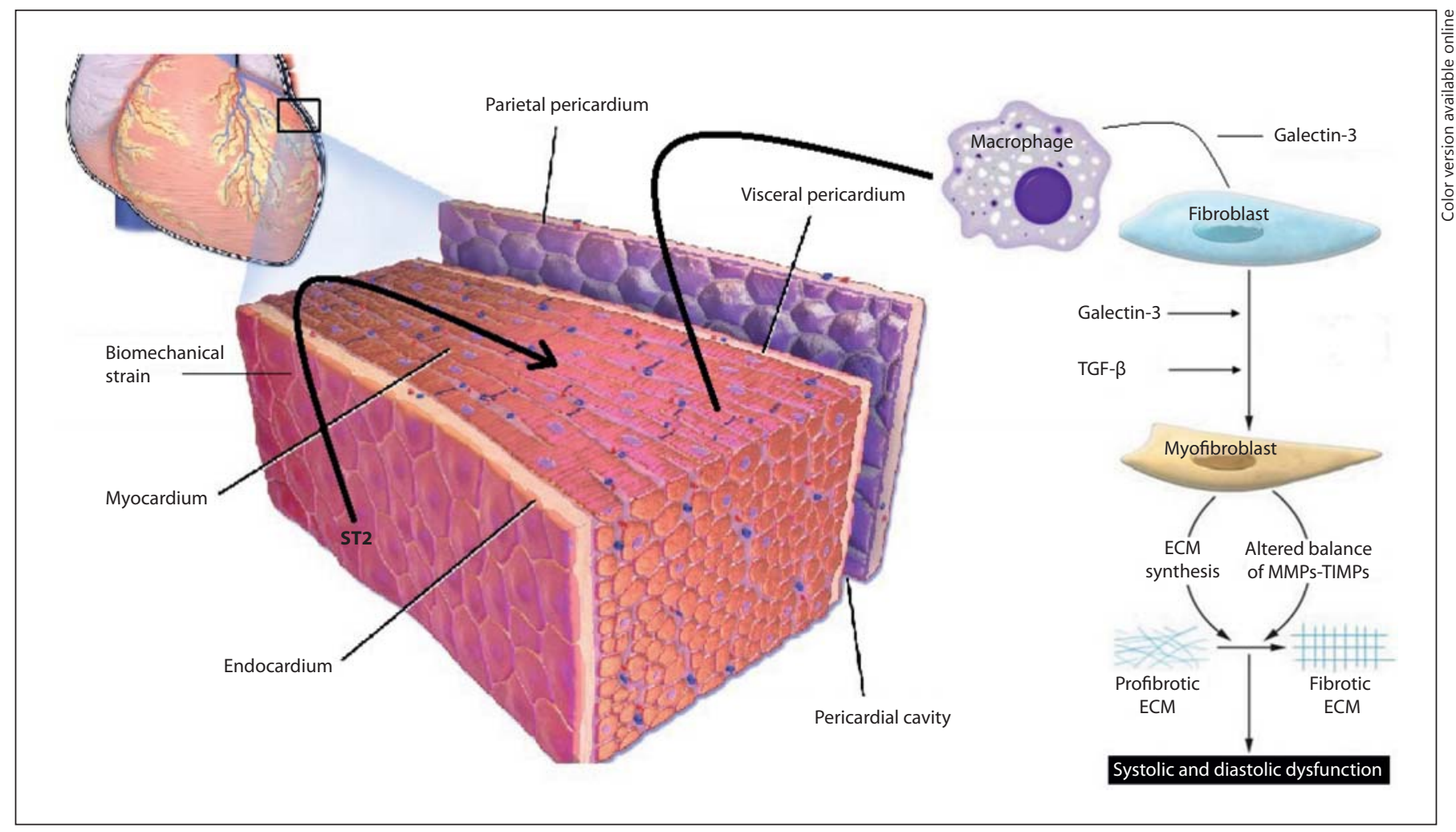

Fig. 3. Roles of ST2 and galectin-3 in pathogenic cardiac fibrosis. MMP = Matrix metalloproteinase; TIMP = tissue inhibitor of metalloproteinase. 
Fig. 4. Risk of incident heart failure in the Framingham Heart Study according to baseline galectin-3.

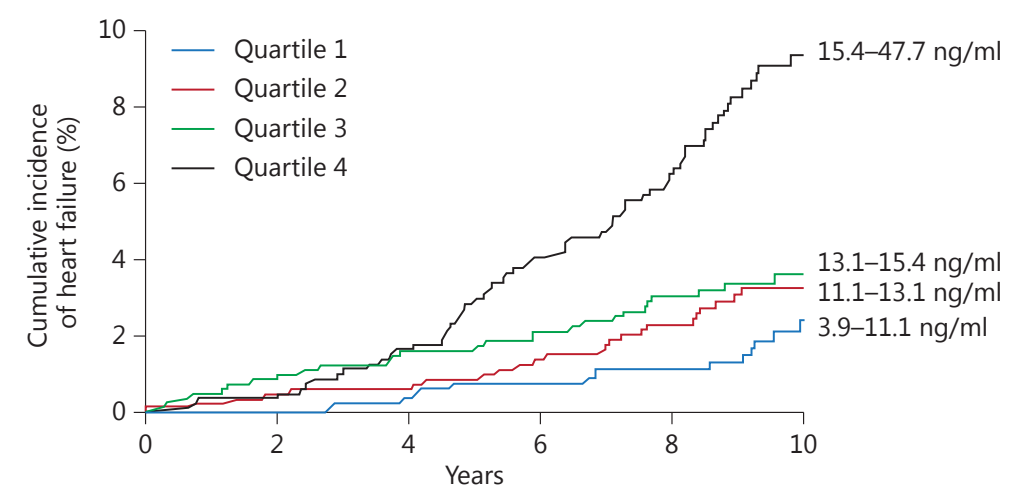

Number at risk

$\begin{array}{lllllll}\text { Quartile 1 } & 835 & 811 & 760 & 747 & 702 & 278\end{array}$

$\begin{array}{lllllll}\text { Quartile } 2 & 842 & 808 & 762 & 736 & 661 & 235\end{array}$

$\begin{array}{lllllll}\text { Quartile } 3 & 842 & 801 & 755 & 726 & 647 & 233\end{array}$

$\begin{array}{llllll}\text { Quartile } 4 & 834 & 789 & 712 & 662 & 591\end{array}$

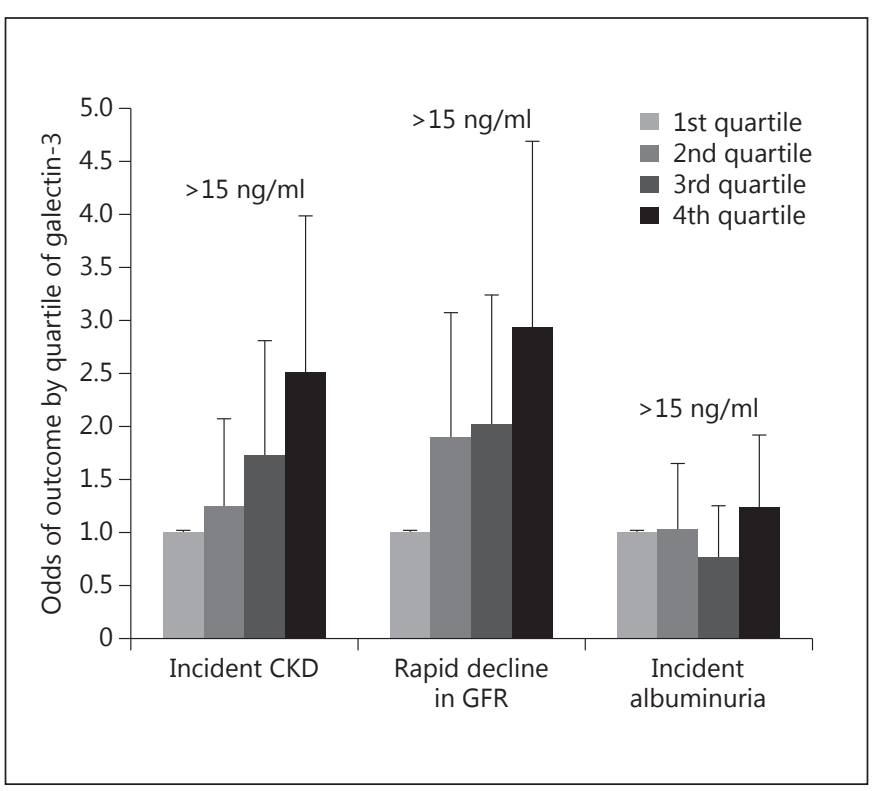

Fig. 5. Multivariate adjusted risk of incident $\mathrm{CKD}$ (defined as an eGFR $<60 \mathrm{~m} / \mathrm{min} / 1.72 \mathrm{~m}^{2}$ ), a rapid decline in eGFR, and incident microalbuminuria according to baseline galectin-3 in the Framingham Heart Study.

compensatory hyperkinesis in order to maintain the change in pressure/time as well as cardiac output [9]. With necrosis of myofibrils, there is slippage of cardiomyocytes and stimulation of satellite cells, most notably macrophages, which can respond with a host of signals to initiate tissue repair, which can work to limit expansion of the chamber. The repair process appears to be highly

Cardiorenal Fibrosis in Cardiorenal Syndromes

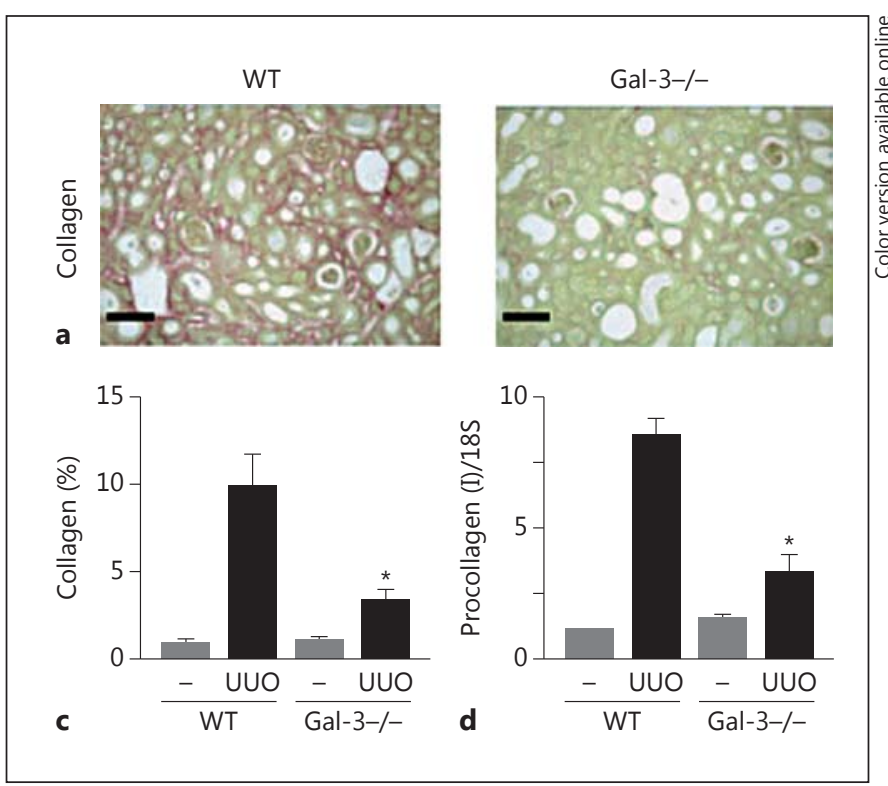

Fig. 6. Renal collagen deposition in a model of acute kidney injury caused by unilateral ureteral obstruction (UUO) in wild-type (WT) and galectin-3 knockout (Gal-/-) animals [adapted from 17].

dependent on the beneficial and direct effects of TGF- $\beta$, which, when manipulated, can influence the degree of inflammation and repair that follows [10]. In the myocardium, fibrosis results in many recognizable clinical features, including PR interval prolongation, heart block, bundle branch block, left ventricular dyssynergy, anisotropy, atrial fibrillation, ventricular arrhythmias, systolic 
Fig. 7. Suggested algorithm for the use of galectin-3 in the management of patients with heart failure [adapted from 23]. NTproBNP $=\mathrm{N}$-terminal proBNP; $\mathrm{MGT}=$ management.

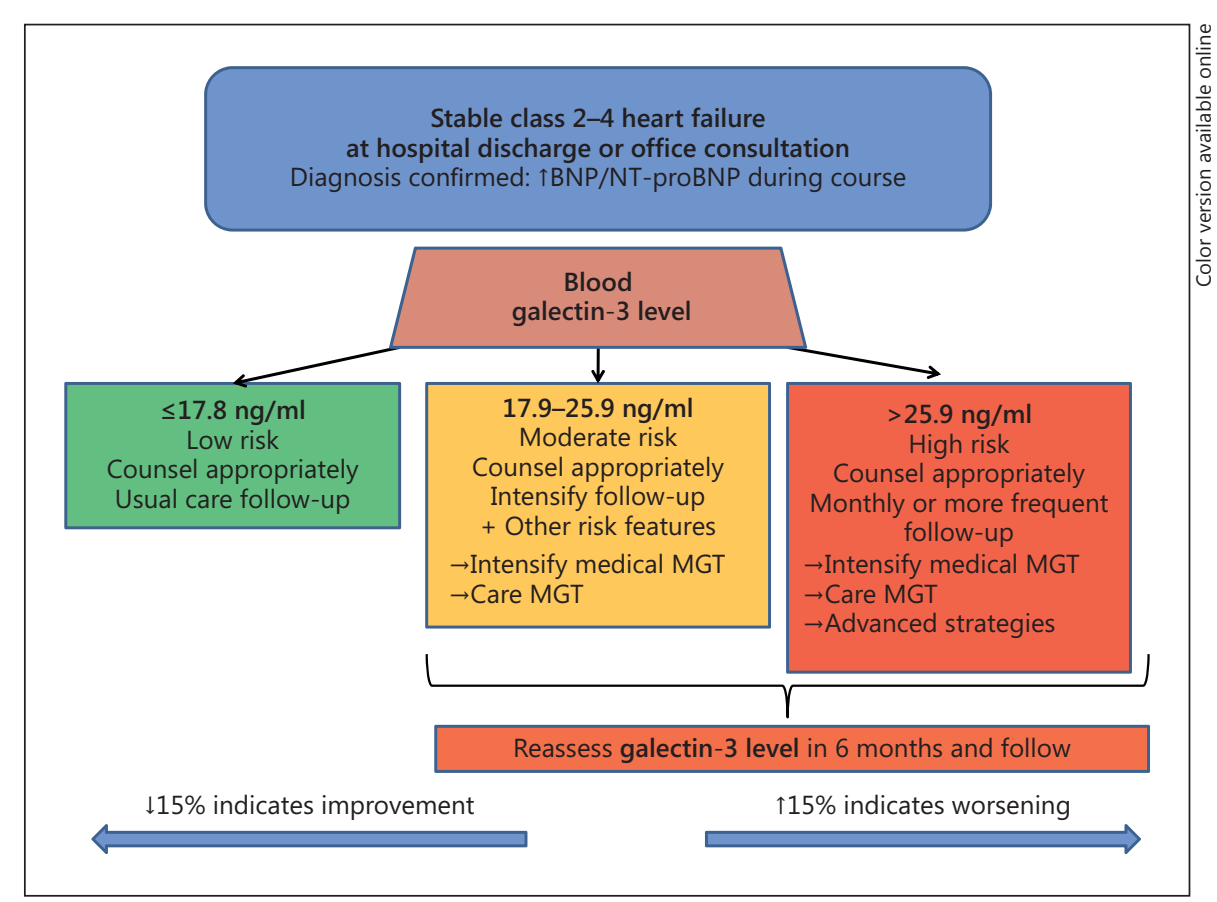

and diastolic dysfunction, heart failure, and cardiac death. These events have yielded measurable in vitro diagnostic assays that give insight into these processes in patients at the bedside.

\section{Natriuretic Peptides, ST2, and Galectin-3}

Clinicians have learned to rely on a normal heart hormone, B-type natriuretic peptide (BNP) and its inactive fragment $\mathrm{N}$-terminal proBNP, part of a family of natriuretic peptides, including atrial natriuretic peptide, and $\mathrm{C}$ - and D-type natriuretic peptide, as an in vitro diagnostic test in patients with suspected or confirmed heart failure. Since the left ventricle has the greatest mass, it is considered the major source of circulating plasma BNP in the human body [11]. Recently, it has been appreciated that in addition to BNP, the endocardium and endothelial cells of the proximal aorta and to a lesser extent the distal vasculature secrete ST2, which is a decoy protein that reduces the opportunity for interleukin-33 to attach to its receptor on cardiomyocytes in response to biomechanical strain, particularly in the setting of left ventricular dysfunction [12]. While BNP is responding to increased wall tension and promoting vasodilation, increased left ventricular lusitropy, natriuresis, and diuresis, ST2 responds to biomechanical stress and by inhibiting interleukin-
33 appears to worsen cardiomyocyte function, promote apoptosis, and autophagy $[13,14]$. In addition, ST2 appears to be directly related to TGF- $\beta$ activity in the interstitium and may promote cardiac fibrosis through unknown mechanisms. Finally, galectin-3, an important secretory product of macrophages, which is involved in cell signaling on the cell surface of integrins, helps translate the TGF- $\beta$ signal within fibroblasts resulting in transformation into myofibroblasts and the upregulation of the cell cycle with the production and secretion of procollagen I into the ECM [15]. In addition, TGF- $\beta$ inhibits metalloproteinases enabling the accumulation and crosslinking of procollagen I in the extracellular space to form mature collagen. The result is histopathological tissue fibrosis in the myocardium.

\section{Renal Fibrosis in Response to Acute and Chronic Injury}

Despite the absence of biomechanical strain and hemodynamic interactions at the macro-organ level, the kidney responds to an array of common chronic diseases by activation of immune cells and satellite cells, including macrophages and fibroblasts, and many of the mechanisms discussed above with TGF- $\beta$ result in both glomerular and tubulointerstitial fibrosis [16]. Because the $\sim 1$ 
million nephrons decline as part of senescence over the course of a lifetime, it is possible that some degree of nephron loss and resultant healing fibrosis could be considered 'normal'. However, in common diseases such as diabetic nephropathy, polycystic kidney disease, and following acute kidney injury, renal fibrosis is considered an exuberant response and is likely pathogenic in the further progression of kidney disease and continued loss of functioning nephrons. As in the myocardium, galectin-3, by assisting in the translation of the TGF- $\beta$ signal, has been implicated in renal fibrosis. In a unilateral ureteral obstruction model, galectin-3 knockout animals appear to have considerably less renal fibrosis in response to this injury than wild-type animals [17]. In addition, in a highdose folic acid model of acute kidney injury, an inhibitor of galectin-3 (modified citrus pectin) appears to reduce renal fibrosis in the days of healing after the injury [18]. Hence, there is evidence that despite a host of mediators upstream of fibrosis, it appears that TGF- $\beta$ and galectin- 3 are prominently involved in kidney fibrosis.

\section{Clinical Measurement of Biomarkers in Chronic Cardiorenal Syndromes}

While many of the factors discussed in this review are local paracrine substances secreted within tissues, some do achieve a sufficient concentration in plasma to be measured by immunoassays. The Framingham Heart Study found galectin-3 levels $>15.4 \mathrm{ng} / \mathrm{ml}$ were strongly associated with the future development of heart failure [19]. In the same cohort, galectin-3 levels $>15.0 \mathrm{ng} / \mathrm{ml}$ were associated with the development of incident CKD defined as an estimated glomerular filtration rate (eGFR) that fell below $60 \mathrm{ml} / \mathrm{min} / 1.73 \mathrm{~m}^{2}$ [20]. Galectin-3, however, was not associated with the development or worsening of albuminuria. The prognostic value of baseline galectin-3 levels has been evaluated in patients with heart failure. A threshold value of $>17.8 \mathrm{ng} / \mathrm{ml}$ or a $15 \%$ change from baseline has been associated with significantly more heart failure hospitalizations and increased mortality compared with lower and stable/decreasing levels [21,22].

$\mathrm{McCullough}$ et al. [23] have proposed a heart failure management algorithm basing the intensity of outpatient management in part on the serial measurement of galectin-3.

A high ST2 level was also used to predict adverse outcomes in heart failure [24]. The 2013 American Heart Association/American College of Cardiology Guidelines list both ST2 and galectin-3 as class IA indications for addi- tive risk stratification of patients with acute or chronic heart failure given their roles as biomarkers of myocardial injury and myocardial fibrosis (class IIB) [25]. These guidelines have expanded the use of the measurable natriuretic peptides BNP and N-terminal proBNP in the diagnosis and prognosis of heart failure (class IA), for the goal-directed optimization of medical therapy in the office (class IIA), and to guide acutely decompensated heart failure management (class IIB). In general, the data suggest that all of these tests are complementary to one another in risk prediction of heart failure hospitalization or death [26]. The Acute Dialysis Quality Initiative has suggested that novel biomarkers can be implemented and used in conjunction with traditional markers of renal filtration function (serum creatinine and cystatin C) and of kidney damage (urinary albumin) in the assessment of chronic cardiorenal syndromes, however, there are no guidelines that formally indicate the use of these new tests [27].

\section{Conclusion}

While there are numerous upstream mediators of cellular and tissue injury in the heart and kidneys that play a role in the pathogenesis of chronic cardiorenal syndromes, it is believed that TGF- $\beta$ plays a central role in both organs in the pathogenesis of tissue fibrosis. With ST2 in the heart and galectin-3 in both the heart and kidneys as apparently important and measurable clinical markers giving insight into this process, we anticipate that there will be a host of potential diagnostic and therapeutic targets in the future to hopefully influence both organ systems in mitigating the impact of chronic disease.
References

Nephron Clin Pract 2014;127:106-112 DOI: $10.1159 / 000363705$ $\checkmark 1$ McCullough PA: Cardiorenal risk: an important clinical intersection. Rev Cardiovasc Med 2002;3:71-76.

2 McCullough PA: Spectrum of cardiorenal disease. Int J Geriatr Cardiol 2005;2:131-135.

-3 Ronco C, McCullough PA, Anker SD, Anand I, Aspromonte N, Bagshaw SM, Bellomo R, Berl T, Bobek I, Cruz DN, Daliento L, Davenport A, Haapio M, Hillege H, House A, Katz NM, Maisel A, Mankad S, Zanco P, Mebazaa A, Palazzuoli A, Ronco F, Shaw A, Sheinfeld G, Soni S, Vescovo G, Zamperetti N, Ponikowski P; Acute Dialysis Quality Initiative (ADQI) Consensus Group: Cardiorenal syndromes: an executive summary from the consensus conference of the Acute Dialysis Quality Initiative (ADQI). Contrib Nephrol 2010; 165:54-67.
Cardiorenal Fibrosis in Cardiorenal Syndromes 
4 Tumlin JA, Costanzo MR, Chawla LS, Herzog CA, Kellum JA, McCullough PA, Ronco C: Cardiorenal syndrome type 4: insights on clinical presentation and pathophysiology from the eleventh consensus conference of the Acute Dialysis Quality Initiative (ADQI). Contrib Nephrol 2013;182:158-173.

5 McCullough PA: Cardiorenal syndromes: pathophysiology to prevention. Int J Nephrol 2010;2011:762590.

6 Tampe D, Zeisberg M: Potential approaches to reverse or repair renal fibrosis. Nat Rev Nephrol 2014;10226-10237.

-7 Cruz DN, Schmidt-Ott KM, Vescovo G, House AA, Kellum JA, Ronco C, McCullough PA: Pathophysiology of cardiorenal syndrome type 2 in stable chronic heart failure: workgroup statements from the eleventh consensus conference of the Acute Dialysis Quality Initiative (ADQI). Contrib Nephrol 2013 182:117-136.

8 Finnson KW, McLean S, Di Guglielmo GM, Philip A: Dynamics of transforming growth factor beta signaling in wound healing and scarring. Adv Wound Care (New Rochelle) 2013;2:195-214.

-9 Schmidt WG, Sheehan FH, von Essen R, Uebis R, Effert S: Evolution of left ventricular function after intracoronary thrombolysis for acute myocardial infarction. Am J Cardiol 1989;63:497-502.

10 Rainer PP, Hao S, Vanhoutte D, Lee DI, Koitabashi N, Molkentin JD, Kass DA: Cardiomyocyte-specific transforming growth factor $\beta$ suppression blocks neutrophil infiltration, augments multiple cytoprotective cascades, and reduces early mortality after myocardial infarction. Circ Res 2014;114:1246-1257.

-11 McCullough PA: Natriuretic peptides in patients with renal failure; in Adams JE, Jaffe AS, Apple F (eds): Markers in Cardiology: A CaseOriented Approach. Malden, Blackwell Futura, 2007, chapt 14, pp 170-180.

12 Ciccone MM, Cortese F, Gesualdo M, Riccardi R, Di Nunzio D, Moncelli M, Iacoviello M, Scicchitano P: A novel cardiac bio-marker: ST2: a review. Molecules 2013;18:1531415328.

13 Hanson ID, McCullough PA: B-type natriuretic peptide: beyond diagnostic applications; in Bakris GL (ed): The Kidney in Heart Failure. New York, Springer, 2012, pp 67-77.
14 Januzzi JL Jr: ST2 as a cardiovascular risk biomarker: from the bench to the bedside. J Cardiovasc Transl Res 2013;6:493-500.

15 de Boer RA, Voors AA, Muntendam P, van Gilst WH, van Veldhuisen DJ: Galectin-3: a novel mediator of heart failure development and progression. Eur J Heart Fail 2009;11: 811-817.

16 McCullough PA, Kellum JA, Haase M, Müller C, Damman K, Murray PT, Cruz D, House AA, Schmidt-Ott KM, Vescovo G, Bagshaw SM, Hoste EA, Briguori C, Braam B, Chawla LS, Costanzo MR, Tumlin JA, Herzog CA, Mehta RL, Rabb H, Shaw AD, Singbartl K, Ronco C: Pathophysiology of the cardiorenal syndromes: executive summary from the eleventh consensus conference of the Acute Dialysis Quality Initiative (ADQI). Contrib Nephrol 2013;182:82-98.

17 Henderson NC, Mackinnon AC, Farnworth SL, Kipari T, Haslett C, Iredale JP, Liu FT, Hughes J, Sethi T: Galectin-3 expression and secretion links macrophages to the promotion of renal fibrosis. Am J Pathol 2008;172: 288-298.

18 Kolatsi-Joannou M, Price KL, Winyard PJ, Long DA: Modified citrus pectin reduces galectin-3 expression and disease severity in experimental acute kidney injury. PLoS One 2011;6:e18683.

19 Ho JE, Liu C, Lyass A, Courchesne P, Pencina MJ, Vasan RS, Larson MG, Levy D: Galectin-3, a marker of cardiac fibrosis, predicts in cident heart failure in the community. J Am Coll Cardiol 2012;60:1249-1256.

20 O'Seaghdha CM, Hwang SJ, Ho JE, Vasan RS, Levy D, Fox CS: Elevated galectin-3 precedes the development of CKD. J Am Soc Nephrol 2013;24:1470-1477.

21 van der Velde AR, Gullestad L, Ueland T, Aukrust P, Guo Y, Adourian A, Muntendam $\mathrm{P}$, van Veldhuisen DJ, de Boer RA: Prognostic value of changes in galectin-3 levels over time in patients with heart failure: data from $\mathrm{CO}$ RONA and COACH. Circ Heart Fail 2013;6: 219-226.
22 de Boer RA, van Veldhuisen DJ, deFilippi C, Muntendam P, Adourian AS, Guo Y, Januzzi $\mathrm{JL}$ : Plasma galectin-3 is associated with nearterm rehospitalization in heart failure: a meta-analysis. J Card Fail 2011;17:S93.

23 McCullough PA, Olobatoke A, Vanhecke TE: Galectin-3: a novel blood test for the evaluation and management of patients with heart failure. Rev Cardiovasc Med 2011;12:200210

24 Ky B, French B, McCloskey K, Rame JE, McIntosh E, Shahi P, Dries DL, Tang WH, Wu AH, Fang JC, Boxer R, Sweitzer NK, Levy WC, Goldberg LR, Jessup M, Cappola TP: High-sensitivity ST2 for prediction of adverse outcomes in chronic heart failure. Circ Heart Fail 2011;4:180-187.

25 Yancy CW, Jessup M, Bozkurt B, Butler J, Casey DE Jr, Drazner MH, Fonarow GC, Geraci SA, Horwich T, Januzzi JL, Johnson MR, Kasper EK, Levy WC, Masoudi FA, McBride PE, McMurray JJ, Mitchell JE, Peterson PN, Riegel B, Sam F, Stevenson LW, Tang WH, Tsai EJ, Wilkoff BL; American College of Cardiology Foundation; American Heart Association Task Force on Practice Guidelines: 2013 ACCF/AHA guideline for the management of heart failure: a report of the American College of Cardiology Foundation/American Heart Association Task Force on Practice Guidelines. J Am Coll Cardiol 2013;62:e147e239.

26 Bayes-Genis A, de Antonio M, Galán A, Sanz H, Urrutia A, Cabanes R, Cano L, González B, Díez C, Pascual T, Elosúa R, Lupón J: Combined use of high-sensitivity ST2 and NTproBNP to improve the prediction of death in heart failure. Eur J Heart Fail 2012;14:32-38.

27 McCullough PA, Bouchard J, Waikar SS, Siew ED, Endre ZH, Goldstein SL, Koyner JL, Macedo E, Doi K, Di Somma S, Lewington A, Thadhani R, Chakravarthi R, Ice C, Okusa MD, Duranteau J, Doran P, Yang L, Jaber BL, Meehan S, Kellum JA, Haase M, Murray PT, Cruz D, Maisel A, Bagshaw SM, Chawla LS, Mehta RL, Shaw AD, Ronco C: Implementation of novel biomarkers in the diagnosis, prognosis, and management of acute kidney injury: executive summary from the tenth consensus conference of the Acute Dialysis Quality Initiative (ADQI). Contrib Nephrol 2013;182:5-12. 